\title{
現地型農業体験学習のプログラム開発と学習プロセス
}

\author{
鈴木曜（神戸大学大学院農学研究科） \\ 板倉 礼実（神戸大学大学院農学研究科） \\ 中塚 雅也（神戸大学自然科学系先端融合研究環）
}

\section{On-farm Experiential Learning Program and Learning Process}

\author{
Yo Suzuki (Kobe University) \\ Ayami Itakura (Kobe University) \\ Masaya Nakatsuka (Kobe University)
}

This study pursued the development of an on-farm experiential learning program through an empirical study of an agricultural educational program in Kobe University. The study was undertaken for two purposes. One was to show the management factors that are essential for operating an on-farm experiential learning program. The choice of educational sites, traffic access, team separation, and time management

\section{1. はじめに}

近年, 食農教育が活発であり, その一形態として の農業体験学習は, 幼児教育から大学教育にいたる までさまざまに実施されている。

大学に扔ける農業体験学習については, 先進的 な取り組みの内容紹介や個別のプログラムの課題 なぞが既往研究として報告されている。これらを 大別すると附属農場に和ける実習と, 農村などの 地域に打ける現地型農業体験学習に分けられる. 前者については澤登 [1] による大学の農場に打け る有機農業の実習事例報告などがあり, 後者につ いては, 中島ら [2] が大学の農学系カリキュラム として，学生と地域住民の連携によるプログラム を展開している.

本研究では特に，後者の現地型体験学習に注目し たい，農場実習では得られない, 農村の現場で直接, 農家の指導を仰ぐことが，生活の場・生計の場とい ら現場ならではの学びを学習者に提供するものと考 えたからである. 中島らの研究では地域と学生の関 係性に注目した研究が行われてきたが，プログラム の企画の要点は明らかにされていない. of farming activities were the main concerns. The other purpose was to show the essential factors of program planning through an analysis of the learning process. The study results showed that an on-farm experiential learning program should include activities such as village roaming, biological surveys, sequential experience from food production to sales, and communication between farmers and students.

そこで本研究では, 神戸大学農学部で開講されて いる「農業農村フィールド演習」を事例として，プ ログラムの企画の要点を確立することを目的とす る。本事例に関してはこれまで，宇野ら［3]，板倉 ら［4]方既に，試験開講であった 2007 年度の取組 を対象に，その教育的効果や運営上の課題を明らか にしている、しかしながら，望ましい現地型農業体 験学習のあり方，プログラムについては確立される に至っていない，

そこで，本稿では，正式科目となった 2008 年度 の取組をも踏まえ, 改めてプログラム開発の過程を 分析することにより，大学教育の一環として，農村 での体験学習を企画運営する際の要点を示すことを 第一の目的とする (フレームの問題)。また，その 一方で，学生の気づきや意識などの学習プロセスを 詳細に分析することにより，実習プログラムを作成 する上での要点を示すことを第二の目的とする（プ ログラムの問題)。な抒，ここで述べる学習プロセ スとは, 各受講学生の知識や技術の内面化や意欲・ 関心の高まりなどの過程を指す。 


\section{2. 研究の方法}

本研究は, 神戸大学農学部の「農業農村フィール ド演習」を対象とした事例研究である. 演習は, 2007 年に試験開講され，2008 年に正式科目として開講さ れた現地型農業体験学習の取組である。兵庫県篠山 市の農家にて演習は挆こなわれ，ほぼ月 1 回，年間 計 8 回，休日に日帰りにて実施されてきた。 大学発 は朝 8 時で，大学のバスにて往復する. 演習の対象 学年は主に農学部の 1 年生であり, 単位は 1 単位と なっている. 他学部生の受講は認められていない.

分析は，実習に関わる教職員への聞き取り調査， 受講学生を対象に，実習前後におこなってきたアン ケート調查 $(2007 / 6 / 17 ， 2008 / 1 / 12 ， 2008 / 4 / 11$, 2009/1/10 実施）を基に打こなった。また，2008年 度については, 学生の気づきや意識変化を探るため, 参加学生に義務づけされている「演習ノート」を分 析するとともに, 参加者のうち 5 名を抽出し, 詳細 な聞き取り調查（2008/11/7-27 実施）によりデー タを収集した。

\section{3. プログラムの企画運営}

\section{（1） 2007 年度の成果と課題}

2007 年度の参加人数は 29 名（うち女性 21 名） であり, 演習地は兵庫県篠山市にある 5 地区であっ た. 学生は希望により市民農園班（東沢田）と農家 班に分けら机，農家班はさらに 4 地区（垂水，小多 田，菅，川北）に分か机た。班の人数は 4 名から 10 名であった。演習は 6 月中旬から 1 月中旬まで 開講された. 2007 年度の主なプログラム概要は表 1 の通りだが，市民農園班は主に伝統栽培作物の黒大 豆の栽培を中心とした作業を行い，農家班はそれぞ れの農家の作業の手伝いを中心とした作業内容であ り，概要と異なる部分がある.

表 1. 2007 年度のプログラム概要

\begin{tabular}{c|c|c|c}
\hline \hline 回 & 日程 & 出席者 & 作業 \\
\hline 1 & $6 / 17$ & 27 人 & 播種 \\
\hline 2 & $7 / 8$ & 28 人 & 中耕培土・除草・追肥・敷きわら \\
\hline 3 & $7 / 29$ & 23 人 & 中耕培土・除草・追肥・支柱立て \\
\hline 4 & $9 / 8$ & 25 人 & 除草・病害虫防除 \\
\hline 5 & $10 / 6$ & 25 人 & 枝豆収穫 \\
\hline 6 & $11 / 24$ & 21 人 & 葉落とし・乾燥 \\
\hline 7 & $12 / 8$ & 25 人 & 黒大豆収穫 \\
\hline 8 & $1 / 12$ & 24 人 & 支柱作り・修了式 \\
\hline
\end{tabular}

プログラムを通しての学習記録として演習ノート がある. 初回にノートの記述方法を提示した上で, 全期を通じて学生に 1 回以上の提出を促し，教員は コメントを返すこととした。 ノートの教育効果とし て，(1)現場の生産者に技術と考方方を学ぶ，(2)農村 の空気を五感で味わら，といら二点についての学習 記録として有効であると認められた ${ }^{1}$.

2007 年度の活動の成果として, 農家班では学生 が少なく, 農家が必要とする農作業を手伝う形式で あったため，学生と農家とのコミュニケーションが 緊密で，双方の満足度が高かった，一方，問題点と しては，第一に市民農園班の作業内容や作業量が あった．市民農園班は，休講措置等の影響で教員が 指導にあたった，そのため，農家との交流や農村生 活の体験がなく, 作業労働が多すぎるなぞの理由で, 活動内容の見直しを求める声が学生と教員からあげ られた．第二に，移動時間の問題があった．各地区 間は車で 10 分から 40 分ほどかかり，送迎時間が長 く作業時間が少なくなる傾向にあった。第三に，農 家と学生の交流ッールとして，学生の質問に生産者 が答える掲示板を設けたが，生産者側のメリットが 不明確などの理由で機能しなかった．演習終了後の アンケート調査では，学生から「地域へ貢献できる 活動」,「地区間での差異の縮小」,「黒大豆以外の栽 培」, 「学生同士や農家との交流機会の増加」が求め られる改善点として上位項目に挙げられた ${ }^{2)}$.

このように，「農業農村フィールド演習」の 2007 年度の試験開講では, (1)市民農園班の活動の見直し, (2)各班の作業内容と作業量の格差是正，(3)移動時間 の短縮と作業時間の拡大，(4)学生と農家の交流ッ一 ルの開発，(5)地域貢献となる活動の実施，(6)黒大豆 以外の農業体験の実施，が課題として残った。

\section{表 2. 2008 年度のプログラム概要}

\begin{tabular}{|c|c|c|c|}
\hline 回 & 日程 & 出席者 & 作業 \\
\hline 1 & $4 / 26$ & 21 人 & 集落散策/組合見学/草刏り \\
\hline 2 & $5 / 17$ & 29 人 & 田植え/水管理 \\
\hline 3 & $6 / 7$ & 27 人 & 黒大豆播種 / 集落散策 / 土壌講義 \\
\hline 4 & $7 / 26$ & 24 人 & 生物調査/バーベキュー \\
\hline 5 & 9/27 & 23 人 & 稲刈り/精米 \\
\hline 6 & $10 / 18$ & 24 人 & 枝豆・芋収穫・販売体験 / 市街地散策 \\
\hline 7 & $11 / 29$ & 23 人 & 黒大豆收穫／農家へのインタビュー \\
\hline 8 & $1 / 10$ & 24 人 & 振り返り・修了式 \\
\hline
\end{tabular}




\section{（2） 2008 年度の成果と課題}

「農業農村フィールド演習」は, 2008 年度に正式 開講された。 シラバスには演習の目的として「農業 農村の現場の実態と課題を多角的・総合的に理解す る」とあり, 到達目標として, (1)持続可能な農業や ライフスタイルのあり方を考えること，(2)実践と提 案により地域の活性化へ寄与すること, (3)主体的な 問題発見・解決力とコミュニケーション能力を養う こと,の 3 つがあった.

2008 年度の参加人数は 31 名（うち女性 17 名）で あった。演習地を篠山市の真南条上集落に絞り, 5 から 6 名ずつの 6 班に分かれた。 2008 年度の主な プログラム概要を表 2 と示す．演習は 4 月下旬から 開講され, 水稲・黒大豆の栽培や地域環境の調査等 を行った。

2008 年度の活動の成果として, 第一に, 集団で活 動を行らことが増え, 演習終了後のアンケートで「学 生同士の交流」の満足度が高かったよらに, 学生同 土の交流が進んだことがあげられる。第二に, 演習 地を 5 地区から 1 地区に変更したことによって，移 動時間の短縮，農作業打よび講義時間の拡大，各班 の演習内容の格差などが是正された。班の人数は, ばらつきがあったものを $5 ， 6$ 名に統一したことによ り, 作業の振り分けが容易となった. 第三に, 開講 時期を 6 月から 4 月に変更したことによって，より 長期間にわたる現場への関わりや，農家繁忙期の回 避などが可能になった，第四に，黒大豆の栽培以外 に枝豆販売や古代米の栽培なども取り入れられた. 第五に，2007 年度は一回の及であったワークショッ プを, 6 月と最終回の二度に渡り取り入れた. 第六に, 各班の演習レポートをインターネットのブログに揭 載し，学生が情報発信・交流できるようにした。

一方で問題点としては，第一に，1 地区に打ける 集団行動が増えるとともに, 農家と学生のコミュニ ケーションが少なくなったとの声があった. 第二に, 農作業の内容に関する解説や情報提供を求める声が あった。

\section{（3）プログラム企画運営における要点}

2007 年度と 2008 年度を総合比較・評価すると, いずれの年も学生は女子が過半数以上を占めている こと, 農学部一回生の一割弱が参加していること, 専攻別の受講では 3 学科 6 コース全てから受講者が いることがわかった.
2007 年度から 2008 年度にかけて，企画運営の面 で多くの課題が解決または改善されたが，一方で活 動単位が大規模になったため, 農家と学生のコミュ ニケーションが減り, 学生に対する農作業について の説明や情報提供も手薄となる問題が発生した.

以上から，プログラムの企画運営のために基礎と なる要点として, (1)活動場所の選定，移動時間・回 数の検討，(2班の分け方と作業時間・内容と量のバ ランス，などがある。また，プログラムをさらに充 実させるためには, (3)農家と学生, 学生同士のコミュ ニケーションを促進すること, (4)学生への作業説明 と情報提供の充実，(5)複数の農作物に関わる活動内 容を取り入れること, (6)活動に地域貢献活動を取り 入れること，などがある。これらのポイントについ ては, 2009 年度の「農業農村フィールド演習」に 沶いて改善され，実施されている，さらに，課題や 成果をフィードバックする仕組みとして, 学生アン ケートの実施や協力農家とのディスカッションの場 を設けている.

\section{4. 学習プロセスの分析}

\section{（1）活動内容と学生別の学習プロセス}

学習プロセスは, 学生の出身地と農業経験拈よび 性別によって差異があることを想定した。そこで 2008 年度に通年 8 回の授業のらち 6 回以上の参加が ある学生の中から, 出身地の農村・都市別に加光, 農業経験のレベル, 性別に偏りのないように学生 A から E の 5 名を抽出した（表 3)。農業経験は，直接 的・間接的な農業経験を調べる目的で，「家の近くに 田畑があったか」，「農家の拈じ・扔ばがいるか」，「本 物の田畑の土を触ったことがあるか」，「農業実習や 農業体験の経験はあるか」,「農業を手伝ったことが あるか」の 5 項目に「はい」と答えた解の数を示した.

対象者が活動テーマ別飞学習したと考兄ら机る内 容を学生別にキーワードでまとめたものが表 4 であ る. キーワードは対象者のノートの記述内容和よび 聞き取り調査の結果から，簡潔にまとめたものであ る ${ }^{3)}$. 本文中に引用する際には, 「学生記号 + 学習 内容番号」，例光ば，学生 Aの（1）は（A1）のよ らに記述した。

学生ごとに学習プロセスのパターンを見ていく と, 学生 A は農作業の苦労や農業経営の厳しさを繰 り返し実感しながら，次第に生産者への提案を行括 
表 3. ノート分析と聞き取り調査対象者

\begin{tabular}{c|c|c|c}
\hline \hline 学生 & 出身 & 性別 & 農業経験（構成率※) \\
\hline A & 農村部 & 男 & $5(14 \%)$ \\
\hline B & 農村部 & 女 & $4(32 \%)$ \\
\hline C & 都市部 & 女 & $3(14 \%)$ \\
\hline D & 都市部 & 男 & $2(21 \%)$ \\
\hline E & 都市部 & 女 & $1(11 \%)$ \\
\hline
\end{tabular}

※構成率は同農業経験レベルの人数が参加者全体に占める 割合

らとする意欲を身につけていく傾向が見られる，初 回から営農組合に対して興味（A4，A5）を示して いた A にとって，転機となった回は，第 6 回での枝 豆販売であった，手作業によって枝豆を収穫・調整 する苦労を知り（A18），遠方から顧客が次々にやっ てくる枝豆のブランド力に驚く（A19）。聞き取り調 查では，最も印象に残った回として黒豆の栽培（第 3 回）と販売（第6 回）をあげている.この驚きは, 特産物を販売するためのしくみの構想（A22，A23） につながり, 最終回の班の提案についての満足感 （A24）と授業の達成感（A26）につながった.

学生 B は出身地の農村と演習地の篠山市, 自分 の今住んでいる都市部の 3 点の比較の中で, 農村部 飞特有の価値観を探っていく過程が見られる。初回 で, 比較対象として故郷を思い出している（B3）が, 特に問題意識の転機となったのは, 第 4 回の生物調 查であった．幼少時代を思い出しながら（B18）, 原風景の必要性 (B19) や田舎の価值を再発見 (B21) している。 これらは，伝統技術への関心（B23）や 都市住民の生きる力の喪失感（B24）などの問題意 識の高まりに影響していったと考兄られる.一方で, 集落散策（第 3 回）では，農村生活に関わる交通の 不便さ（B17）を感じ，教育環境の不備（B35）飞 ついても問題意識を広げていく。しかし, 演習の最 終回には欠席したため, 問題を具体的な対策や提案 などに結びつけて行く過程はデータから把握するこ とはできない。

学生 C については活動内容を通じての特定の傾 向は発見できなかった，聞き取り調査では，多くの プログラムが印象に残っていると答えて拈り（第 2 , 4，5，6回)，体験学習自体は有意義であったと考 兄らるが，独自の問題意識の発展までにはつなが らなかった可能性もある。農村生活への関心 (C10) があり, 第 4 回で, 川の污さへの驚きから地域美化
の必要性を認識した（C4）。また，第 7 回で農家へ インタビューをしたことを通じて，現場の農業や農 村に関連する問題への理解を深めていった (C7, C8，C9）と言えるだろう。体験学習の弱点として あげられることのある「体験だけ学習」にならない 上う，特に印象に残った活動内容に絞って，個人的 な振り返りや事後学習を促すことも必要となる.

学生 D は，農業とは疎遠な自らの生い立ち（D1） を意識しながらも，初めて体験する農作業に驚き （D6）ながら，生産の工夫に興味を募らせていく過 程がうかが光る（D7，D10，D11，D14，D18）。特 に第 6 回の枝豆の販売では，黒豆の人気を目の当た りにして (D20), その販売方法の魅力を考察し (D21) 消費者への対応に関心を寄せている(D22)。これは， 第 7 回で観光客への黒豆販売の提案（D24）を試み ることにつながっていく，最終回には自ら発表した 提案を物足りなく感じ（D26），事後学習へとつな ゲていく学習意欲が生まれた（D27）.

学生 $\mathrm{E}$ は, 生産や消費の体験を通じて, 消費者 としての自らを振り返る姿勢が芽生えた，初めての 田植光（第 2 回）が特に印象に残って打り，農業者 の苦労を意識し（E1），植えた稲の生育が楽しみに なった（E2）。農業の生産から出荷にいたる工程の 複雑さなぞに驚き（E5，E6，E11），素人に簡単に まねができるものではない（E12）と感じるに至る. こうした考光から，消費者としての自らを振り返る ようになった（E23）。一方で，都市部と農村部の 違いを意識し（E20），生物調査（第 4 回）で生物 多様性の重要性に気づく（E8）とともに，人間中 心の生活を改める決意（E9）をする.

ここで，学生にとって転機となった活動内容につ いて再考したい：活動のテーマと出身地の違いにつ いて注目すると, 農村部出身者である学生 A と B は, 集落散策（第 1 回）と生物調査（第 4 回）で故郷の 風景や生活と篠山市を比較する傾向がある( 1 1, A3，A15，B3，B18）のに対して，都市部の出身者 は初めて目にすることや体験が多い $(\mathrm{C} 1 ， \mathrm{D} 6$, E1)。しかしDのように，風景に新鮮さと懐かしさ を同時に感じる場合（D2）もある。また，出身地 に関わらず，生物調査（第 4 回）は学生 A, B, C, E が印象的であったと述べている，農村の空間を五 感で満䒜し，生物や風景の保全 (A15，A16，B18， $\mathrm{B} 19 ， \mathrm{E} 8)$ ，生物や環境の利用（D14，D15）や管理 
表 4. 学生別学習内容リスト

\begin{tabular}{|c|c|c|c|c|c|c|}
\hline 回 & 活動 & 学生 A & 学生 B & 学生 C & 学生 D & 学生 E \\
\hline \multirow{3}{*}{1} & 集落散策 & $\begin{array}{l}\text { (1) 故郷の風景との比較 } \\
\text { (2) 外来種の影響への驚き } \\
/ \text { (3) 馴染みの植物の発見 }\end{array}$ & $\begin{array}{l}\text { (1) 獣害対策への関心 / (2) } \\
\text { 分水領への興味 }\end{array}$ & 欠席 & $\begin{array}{l}\text { (1) 農業と疎遠な育ちの認 } \\
\text { 識 (2) 新鮮さと懐かし } \\
\text { さの実感/ (3) 絶滅危惧 } \\
\text { 種への祭心 }\end{array}$ & 欠席 \\
\hline & 組合見学 & 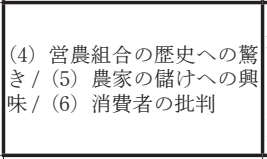 & 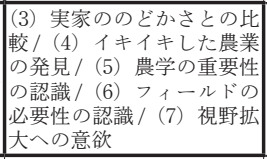 & & - & \\
\hline & 草刈り & （7）農作業の難しさの実感 & $\begin{array}{l}\text { (8) 工夫された農具への関 } \\
\text { 心 }\end{array}$ & & $\begin{array}{l}\text { (4) 草刈りの苦労の䒠感/ } \\
\text { (5) 農業の過酷さの認識 }\end{array}$ & \\
\hline \multirow[b]{2}{*}{2} & 田植光 & $\begin{array}{l}\text { (8) 獣害対策への関心 / (9) } \\
\text { 体験済久農作業への自信 }\end{array}$ & - & \begin{tabular}{|l|} 
(1) 初の田植えと苦労の実 \\
感/感
\end{tabular} & $\begin{array}{l}\text { (6) 初の田植えと苦労の実 } \\
\text { 感 / (7) 農業機械への興味 }\end{array}$ & $\mid \begin{array}{l}\text { (1) } \text { 田の維持の大変さの認 } \\
\text { 識/ (2) 稲の生育への期待 }\end{array}$ \\
\hline & 水管理 & $\begin{array}{l}\text { (10) 農業経営の厳しさの } \\
\text { 認識 }\end{array}$ & $\begin{array}{l}(9) \text { 森林と農業の関連性の } \\
\text { 認識/ (10) 助讨合いの重 } \\
\text { 要性の認識/ (11) 専攻と } \\
\text { 水管理の関連性の認識/ } \\
(12) \text { 田舎の生命観の認識 }\end{array}$ & - & $\begin{array}{l}\text { (8) 水管理の重要性の認識 } \\
/ \text { （9）森林保水力への関心 }\end{array}$ & $\begin{array}{l}\text { (3) 都市道と山道の違いの } \\
\text { 認識/ (4) 水管理の環境配 } \\
\text { 慮への感動/ (5) 農業の採 } \\
\text { 算の厳しさの認識 }\end{array}$ \\
\hline \multirow{3}{*}{3} & \begin{tabular}{|l} 
黑大豆播 \\
種
\end{tabular} & (11）栽培コストへの関心 & $\begin{array}{l}\text { (13) 黑豆の生命力の強さ } \\
\text { への驚き }\end{array}$ & (3) 栽培の奥深さ & $\begin{array}{l}\text { (10) 黒豆栽培方法への驚 } \\
\text { き/(11) 直播き作業の嚴 } \\
\text { しさの実感 }\end{array}$ & $\begin{array}{l}\text { (6) 栽培工夫への驚き/(7) } \\
\text { 味わうこ感 }\end{array}$ \\
\hline & 集落散策 & - & $\begin{array}{l}\text { (14) ぞふうくの味への驚 } \\
\text { き/(15) 絵になる風景の } \\
\text { 発見/ (16) 農家の自慢話 } \\
\text { の共感/ (17) 不便さの } \\
\text { 認識 }\end{array}$ & - & $\mid \begin{array}{l}\text { (12) 獣害への驚き/ (13) } \\
\text { 農村の魅力の実 }\end{array}$ & - \\
\hline & 土壌講義 & $\begin{array}{l}\text { (12) 肥料の知識への関心 } / \\
\text { (13) 農薬の有益性の検討/ } \\
\text { (14) 消費者への懷疑の認 } \\
\text { 識 }\end{array}$ & - & - & - & - \\
\hline \multirow[t]{2}{*}{4} & 生物調査 & $\begin{array}{l}\text { (15) 昔見たまま来の自然の } \\
\text { 発見/ (16) 生物保全への } \\
\text { 感謝 }\end{array}$ & $\begin{array}{l}\text { (18) 幼少時代との類似点 } \\
\text { の発見/(19) 原風景の必 } \\
\text { 要性の認識/ (20) 都会の } \\
\text { 不完全性の認識/ (21) 田 } \\
\text { 舎の価値の再発見 }\end{array}$ & 識 & $\begin{array}{l}\text { (14) 益虫利用への興味/ } \\
\text { (15) ビオトープ重要性 } \\
\text { の認識 }\end{array}$ & $\begin{array}{l}\text { (8) 生物多様性の重要性の } \\
\text { 認識/ } \\
\text { の反省 }\end{array}$ \\
\hline & $\begin{array}{l}\text { バーベキ } \\
\text { ュー }\end{array}$ & $\begin{array}{l}\text { (17) 米食の PR 方法の検 } \\
\text { 討 }\end{array}$ & - & - & $\begin{array}{l}\text { (16) 地元野菜・肉の美味 } \\
\text { しさの発見 }\end{array}$ & \begin{tabular}{|l|} 
(10) 米・野菜の美味しさ \\
の発見
\end{tabular} \\
\hline 5 & \begin{tabular}{|l} 
稲刈・精 \\
米
\end{tabular} & 欠席 & $\begin{array}{l}\text { (22) 農家のチャレンジ精 } \\
\text { 神への驚き/(23) 伝統技 } \\
\text { 術への関心/ (24) 都市住 } \\
\text { 民の生きる力の喪失感 }\end{array}$ & $\begin{array}{l}\text { (5) 工程の複雑さの実感/ } \\
\text { (6) 農家のコスト感覚への } \\
\text { 関心 }\end{array}$ & $\begin{array}{l}\text { (17) } \text { 田植之の苦労の回顧 / } \\
\text { (18) } \text { 古代米生育環境の検 } \\
\text { 討 / (19) 農作物の貴重さ } \\
\text { の実感 }\end{array}$ & $\begin{array}{l}\text { (11) 出荷工程の工夫への } \\
\text { 驚き/(12) 素人農業の難 } \\
\text { しさの認識/ (13) 機械等 } \\
\text { のコストの関心 } \\
\end{array}$ \\
\hline & 枝豆收穫 & (18) 手作業の苦労の実感 & - & 欠席 & - & - \\
\hline \multirow[t]{2}{*}{6} & 枝豆販売 & $\begin{array}{l}\text { (19) ブランド求心力への } \\
\text { 驚き/(20) 枝豆の美味し } \\
\text { さの実感 }\end{array}$ & $\begin{array}{l}\text { (25) ブランドのしくみの } \\
\text { 発見 }\end{array}$ & & $\begin{array}{l}\text { (20) 顧客の多さへの驚き } \\
\text { (21) 路上販売の魅力の } \\
\text { 検討 / } 22 \text { ) 消費者対応の } \\
\text { 姿勢への関心 }\end{array}$ & 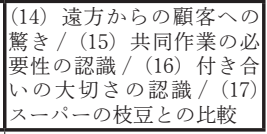 \\
\hline & $\mid \begin{array}{l}\text { 市街地散 } \\
\text { 策 }\end{array}$ & - & $\begin{array}{l}\text { (26) 農村との関わりへの } \\
\text { 反省/(27) 演の将来へ } \\
\text { の影響の検討 }\end{array}$ & & - & - \\
\hline & $\begin{array}{l}\text { 黒大豆 } \\
\text { 收穫 }\end{array}$ & $\begin{array}{l}\text { (21) 研究作物に出会ら驚 } \\
き\end{array}$ & $\begin{array}{l}\text { (28) 芋掘りの大変さの実 } \\
\text { 感 }\end{array}$ & - & - & - \\
\hline 7 & $\mid \begin{array}{l}\text { 農家イン } \\
\text { タビュー }\end{array}$ & $\begin{array}{l}\text { (22) 市街地と集落の連携 } \\
\text { ○の提案/ ( } 23) \text { 直売所大 } \\
\text { 規模化への提案 }\end{array}$ & $\begin{array}{l}\text { (29) 農業の醍醐味と現実 } \\
\text { の認識/ (30) 真南条の活 } \\
\text { 気の要因の検討/ (31) 異 } \\
\text { なる時間軸の実感 } \\
\end{array}$ & $\begin{array}{l}\text { (7) 担い手の問題の認識 } \\
\text { (8) 機械作業の効率の再発 } \\
\text { 見/ (9) 農村の教育機会の } \\
\text { 検討 }\end{array}$ & 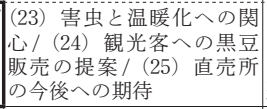 & $\begin{array}{l}\text { (18) 農村の現状の把握/ } \\
(19) \text { プレぜンる提案 } \\
\text { 力の習得/ (20) 価値観の } \\
\text { 違いの認識 }\end{array}$ \\
\hline 8 & 振り返り & $\begin{array}{l}\text { (24) 班の提案への満足感/ } \\
(25) \text { 地元食の美味しさの } \\
\text { 実感/(26) 通年の授業の } \\
\text { 意義の認識 }\end{array}$ & 欠席 & - & $\begin{array}{l}\text { (26) 班の提案への物足り } \\
\text { なさ認識/ (27) 学習意 } \\
\text { 欲の高まり事後学習の実 } \\
\text { 施/ (28) 人手不足解消の } \\
\text { 難しさの認識/ (29) 演習 } \\
\text { の限定性の認識 }\end{array}$ & - \\
\hline & $\begin{array}{l}\text { 記以外のコ } \\
\text { シト }\end{array}$ & - & $\begin{array}{l}\text { (32) 農家の現実と研究の } \\
\text { 乘離認識/ (33) 演翼で } \\
\text { の技術習得の限界の証/ } \\
\text { (34) 故郷の集落と真南条 } \\
\text { の比較/ (35) 農村部の教 } \\
\text { 育環境不備への危機感 }\end{array}$ & （10）農村生活 & $\begin{array}{l}\text { (30) 機能性食品としての } \\
\text { 黒豆への関心 }\end{array}$ & $\begin{array}{l}\text { (21) 子ども時代の遊びの } \\
\text { 違いの認識/ (22) 農業の } \\
\text { 知恵への関心/ (23) 消費 } \\
\text { 者意識の反省 }\end{array}$ \\
\hline
\end{tabular}

注 : 1）一は該当記述・コメントなし.

2) 太枠は, 聞き取り調査の回答から，特に学生の印象に残った活動内容を示す。該当回の無いコメントについては最下部の「上記以外のコメント」 欄に記載した。 
の必要性（C4）について学び，影響を受けた活動 内容であった。

農村部出身者にとって, 営農組合への見学（第 1 回）や枝豆販売（第 6 回）は故郷と比較して見習ら べき農業のあり方として非常に印象に残ったようだ (A4，A5，A19，B4，B22，B25，B30，B34)。また， 枝豆の販売（第 6 回）は，黒豆のブランド力を多く の学生に痛感（A19，D20，E14）させるプログラ ムとなり，生産者と消費者の関係性（D21，D22） やブランドのしくみ（B25）に関して興味や関心を 高める契機となった。

農家へのインタビュー（第 7 回）は，これまで学 生たちが体験し理解を深めてきた農業農村の実態 を，農家との対話から裏づける機会であり，農業の 醍醐味 (B29) とともに, 現実の問題を再認識し (B30, $\mathrm{C} 7, \mathrm{C} 8, \mathrm{C} 9, \mathrm{D} 23, \mathrm{E} 18)$ ，具体的な問題解決への 提案へとつながっていく重要な機会（A22，A23, D24，D25，E19）であった.

\section{（2）プログラム開発のための企画の要点}

このように，学習プロセスをプログラムの活動内 容と対応し把握していくことによって，プログラム の企画の要点が明らかになってきた。

第一に，集落散策活動と生物調査は，農村部出身 者にとっては故郷と演習地を比較し理解を深める手 段として, 都市部出身者にとってはなじみの無い農 村部への導入としての有効性が確認できる。また， 季節を越えて数回にわたり実施することで，自然環 境や社会環境に関して，より深い気づきや理解をも たらす。

第二に，農家と消費者をつなぐ生産から販売まで の工程を, 通年で体験する活動が重要である. 特に 販売の体験は，農業経営の努力と消費者とのつなが りを感じさせる体験となる。

第三に，学生が主体的な問題意識から直接農家に 疑問をぶつけ, コミュニケーションを取る活動が重 要である.プログラム全体の集大成としての振り返 りと発表，農家からの評価も合わせて行らことで, 学生の問題意識が明確化し, コミュニケーション能 力の養成が行わ和ると同時に, 農業農村の課題に対 する理解や意識が深まる。

\section{5. おわりに}

本研究では, 現地型農業体験プログラム開発の企
画の要点を確立することを目的として，神戸大学農 学部で開講されている「農業農村フィールド演習」 を事例に，第一に，現地型農業体験実習を企画運営 する際の要点を示した．企画運営の前提となる活動 場所の選定，移動時間・回数の検討，班分けや作業 時間等のバランスといった基礎的要点に加え，さら に充実したプログラムを目指して，コミュニケーショ ンの促進や作業説明と情報提供, 作業内容の多様化, 地域への貢献活動などが検討されるべきである.

第二に，学生の気づきや意識などの学習プロセ スを詳細に分析することにより，活動内容を企画 する上での要点をまとめた．分析の結果，集落散 策と生物調査の実施，農業の生産から販売までの 工程の体験, コミュニケーションの場の設定が重 要と考えられる.

本研究で取り上げた「農業農村フィールド演習」 の目的にあると打り，本演習は農業農村の実態と課 題を多角的・総合的に理解するための現地型農業体 験学習の有り方を考える上で，一つのモデルプログ ラムとして発展してきたといえる。しかし，本研究 が対象としていない大学農学部生以外の異年齢や異 文化の集団に対する汎用性や，地域や活動内容を越 えての一般化の可能性については, 残された課題と し，より望ましい現地型農業体験学習の有り方を模 索していくこととする。

注 1）宇野 [3] を参照.

2）板倉 [4]を参照.

3）例えば「篠山市に入ると故郷で見た懐かしい風景 が広がっていた（学生 A）」との記述を「故郷の風 景との比較」などとまとめた。

\section{参考文献}

［1］澤登早苗『教育農場の四季』コモンズ，2005, pp. $10-11$.

[2]中島紀一編『地域と響き合う農学教育の新展 開:農学系現代 GP の取り組みから』筑波書房, 2007.

[3] 宇野雄一潘か「現地体験型農業学習の運営方 法の評価」『日本農業教育学会誌』 40,2 , 2009，印刷中.

[4]板倉礼実・中塚雅也・宇野雄一「大学生を対 象とした農業体験学習の意義と課題 : 神戸大 学農学部の取り組みを事例として」『神戸大学 農業経済』40，2008，pp. 33-40. 